TAO, Vol. 12, No. 3, 461-484, September 2001

\title{
Could We Have Pre-located the Northeastern Portion of the 1999 Chi-Chi Earthquake Rupture Using Geological and Geomorphic Data?
}

Meng-Long Hsieh ${ }^{1, \star}$, Yuan-His Lee ${ }^{2}$, Tung-Sheng Shih ${ }^{2}$, Shih-Ting $\mathrm{Lu}^{2}$, and Wei-Yu Wu ${ }^{2}$

(Manuscript received 21 April 2000, in final form 21 June 2001)

\begin{abstract}
The Chi-Chi earthquake rupture that mostly follows the mountain front in central Taiwan bends east/northeast into hills in the Tachia River valley. We found no major pre-existing fault systems in this hill area. However, based on river terrace morphology and sequences, the lower Tachia River valley appears to have been uplifted more rapidly than the lower Taan River valley in the past ten thousands of years, which is consistent with the bend of the earthquake rupture. The earthquake rupture (and associated uplift) also coincides with: (1) straight mountain-front escarpment south of the Tachia River valley; (2) two fault/fold-scarps on the Holocene terraces, and abnormal sideward inclination and downstream flattening of these terraces in the Tachia River valley; (3) local development of non-laterized terraces in the Taan River valley; (4) abnormal rise and narrowing of the Taan/ Tachia drainage divide. These geomorphic anomalies, however, are either local or diffusive; features (1) to (3) might have been interpreted as of fluvial origin. Also, the link between these features and the movement of the Chelungpu-Sanyi fault, the causative fault of the earthquake, might have been uncertain. We thus argue that the pre-location of this portion of the Chi-Chi earthquake rupture would havebeen difficult, even though we could have roughly delineated a potential coseismic deformational zone in the region.
\end{abstract}

(Key words: Pre-location, Chi-Chi earthquake rupture, River terrace, Geomorphic anomaly)

\section{INTRODUCTION}

Perhaps the most unexpected geological feature associated with the 1999 Chi-Chi earthquake $\left(M_{w}=7.6\right)$ is the way the coseismic rupture (and deformation) ended toward the northeast.

\footnotetext{
${ }^{1}$ Department of Geosciences, National Taiwan University, Taipei, Taiwan, ROC

${ }^{2}$ Central Geological Survey, Taipei, Taiwan, ROC

${ }^{\star}$ Corresponding author address: Dr. Meng-Long Hsieh, Department of Geosciences, National Taiwan University, 245 Choushan Road, Taipei, Taiwan, ROC; E-mail: hsieh@ gl.ntu.edu.tw
} 
For more than four fifths of its total length of ca. $100 \mathrm{~km}$, the earthquake rupture strikes north and generally follows the mountain front, or the Chelungpu-Sanyi fault, which separates hills from the Taichung Basin to the west (Fig. 1). The earthquake rupture, however, turns east into the hills where it encounters the Tachia River valley, and father extends northeastward to the Taan River basin (Fig. 1). This pattern of rupture contradicts that of the previously mapped Chelungpu-Sanyi fault, which continues to the mountain front north of the Tachia River valley (Fig. 1; e.g.., Chinese Petroleum Corporation 1974; Bonilla 1977; Chang et al. 1998). In addition, despite its being farthest away from the epicenter, much of this anomalous portion of the rupture has a height more than two times larger than that of the rupture to the south (Central Geological Survey 1999).

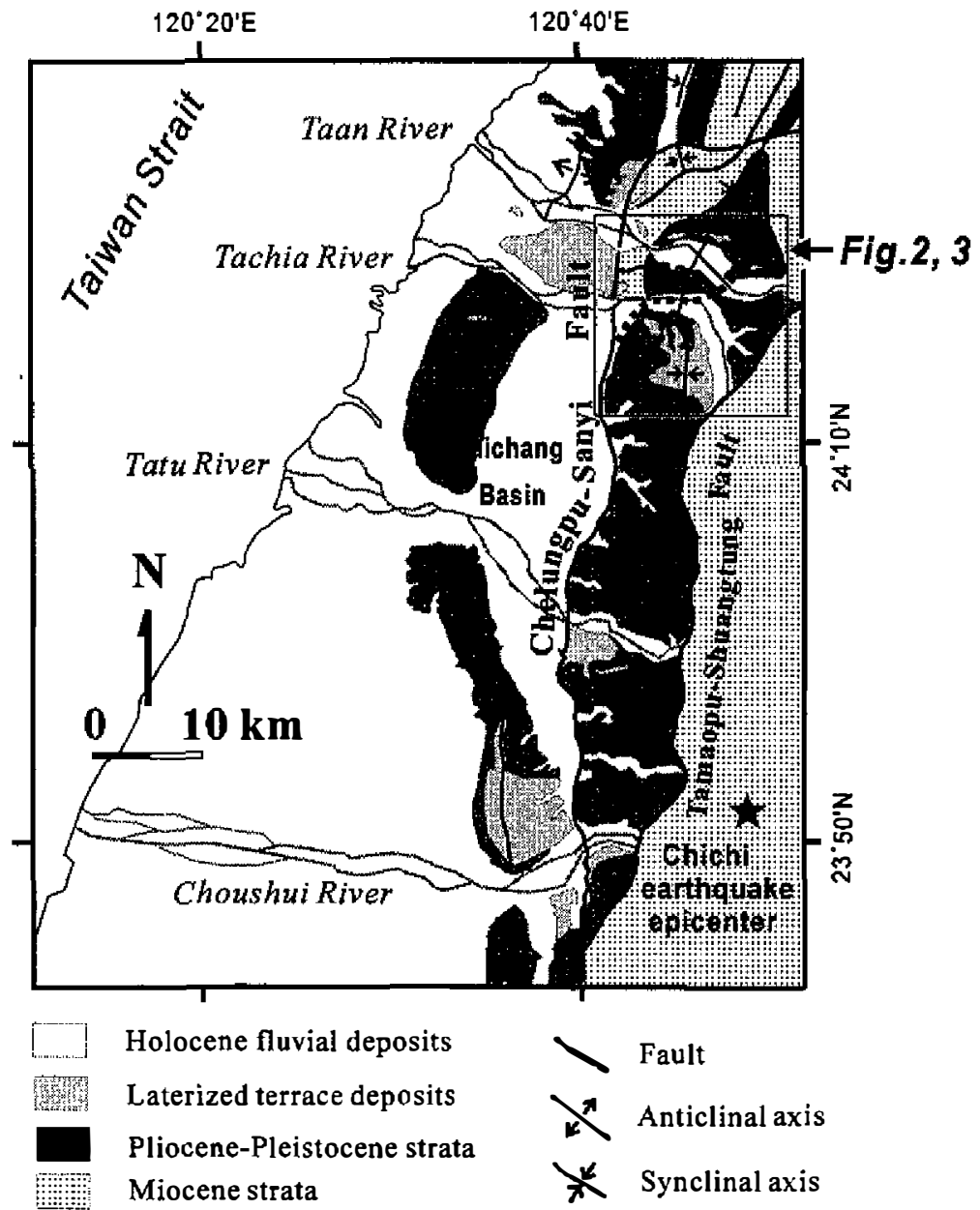

Fig. 1. Geological map of Taichang and its adjacent areas (modified from Chinese Petroleum Corporation 1974, 1982). Dotted line outlines the portion of the Chi-Chi earthquake rupture (and uplift belt) that deviates from the mapped Chelungpu-Sanyi fault system. 
The "anomalies" of this east/northeast-striking portion of the Chi-Chi earthquake rupture prompt important concerns. Does there exist an undetected, major fault system in the Taan/ Tachia river valleys? Could this portion of the earthquake rupture have been predictable if more careful and detailed surveys had been done? If the answers are in the negative, one must face the reality that great earthquakes in the setting of Taiwan potentially can create ruptures that cannot be detected in advance by surface geological surveys. If so, the uncertainty of evaluating seismic hazards of the island would be highly promoted.

On the other hand, there usually exist uncertainties in locating potential earthquake ruptures, or active faults, by applying geological and geomorphic evidence. Geological evidence refers to a relatively long time period, so that it may not reflect the most recent tectonic conditions. Landforms created by tectonic processes also may not be differentiable from those created by other processes, such as fluvial erosion/deposition. It is not until lifetime great earthquakes that these uncertainties in a particular setting can become clarified (for example, if an "old" fault offsetting early Pleistocene strata continues to be active or if an apparent terrace riser is in fact of fault origin). The "anomalies" of the Chi-Chi earthquake thus provide a chance to review the relationship between the earthquake ruptures and their surrounding geological and geomorphic statements. Such an experience and knowledge are certainly valuable for locating potential earthquake ruptures elsewhere on the island.

In this paper, we review geological and geomorphic data around this anomalous portion of the Chi-Chi earthquake rupture. We surveyed the area after the earthquake and found some structures that are not shown on the published geological maps (Torii 1934; Chinese Petroleum Corporation 1974; Lee 2000). We also examined river terraces in the Taan and Tachia river basins, many of which have been mapped by Lin (1957), Shih et al. (1986) and Chen et al. (2000). These geomorphic data were used to recognize possible surface ruptures or deformation that predated the earthquake. Our goal is to explore whether this portion of the earthquake rupture follows any undetected geological and geomorphic boundary (or active stuctures), and how confidently we might have used such a boundary (or structures), if any, to pre-locate this earthquake rupture. We hope that the attempt of this study can prompt more reflection of the limitation and ability to locate potential earthquake ruptures, and help evaluating the island's seismic hazard in the future.

\section{EARTHQUAKE DEFORMATION PATTERN NORTH FROM FENGYUAN}

Central Geological Survey (1999) and Lee et al. (2000) have reported the pattern and geomery of the Chi-Chi earthquake rupture north from Fengyuan. Here we only summarize some key results from them (Figs. 2 and 3; for more information see Figs. 4, 6, 9 and 10). The Chi-Chi earthquake rupture (sometimes expressed as flexure) generally follows the foot of the mountain-front escarpment north from Fengyuan (Fig. 2). The rupture turns east and branches where it enters the Tachia River valley and, somewhat en echelon arranged, creates a 1-2 kmwide uplifted belt that occupies almost the entire valley (Figs. 2 and 3). The rupture (and uplifted belt) follows the Tachia River valley for about $5 \mathrm{~km}$ and extends farther northeast, crossing the major drainage divide, to the Taan River valley (Figs. 2 and 3). The rupture (and 
flexure) has vertical displacements of commonly $>4 \mathrm{~m}$ and is associated with gentle folding or tilting (Fig. 3; profiles AA' to DD'). The uplift created by the earthquake is up to $15 \mathrm{~m}$ in the Tachia River valley and decreases to 5-6 $\mathrm{m}$ in the Taan River valley (Fig. 3; profiles AA' to DD').

\section{GEOLOGICAL DATA}

\subsection{Structural Framework}

The causative fault system of the 1999 earthquake, the Chelungpu fault (or the southern part of the Chelungpu-Sanyi fault system), is a major thrust fault in the central part of the

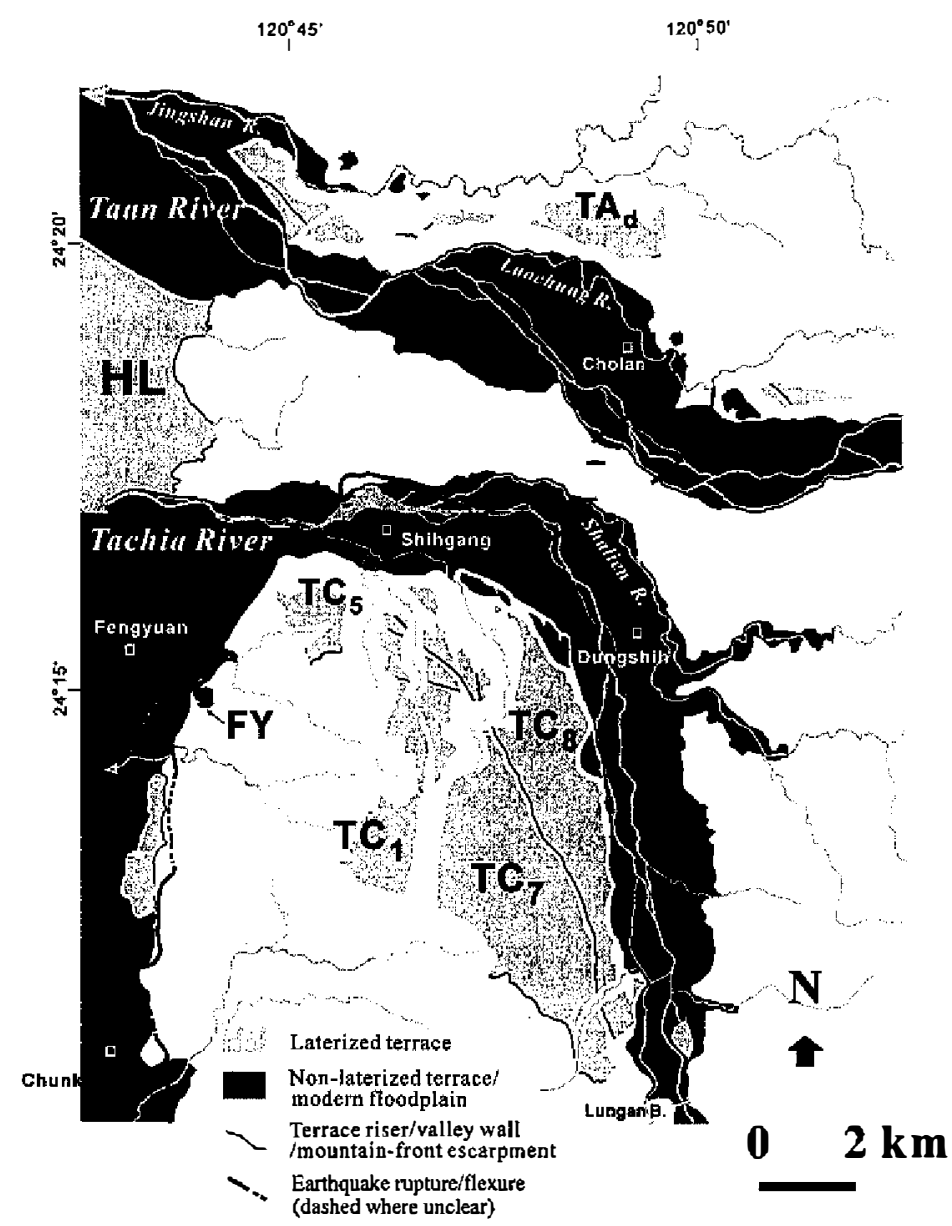

Fig. 2. Overview of the Chi-Chi earthquake rupture (flexure) north from Chunkungliao and the surrounding river systems and terraces. For location see Fig. 1. Summarized from Central Geological Survey (1999) and Lee et al. (2000). 


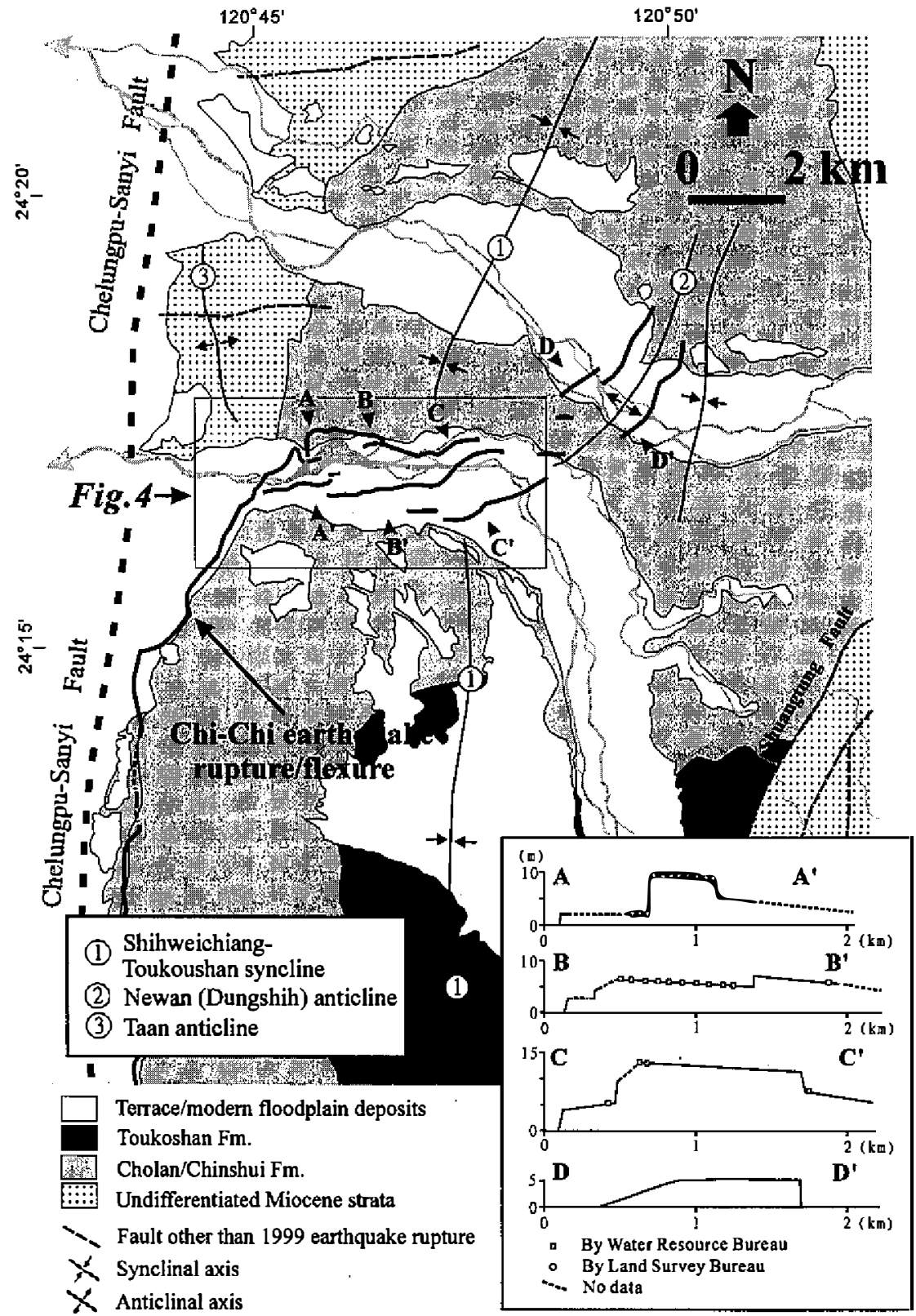

Fig. 3. Overlay of the geological map of the lower Taan and Tachia river basins with the Chi-Chi earthquake rupture (flexure). For location see Fig. 1. Stratigraphic units and structures are modified from Chinese Petroleum Corporation (1974). Inset summarizes profiles of the coseismic deformation based on our field surveys and unpublished data from Water Resource Bureau and Land Survey Bureau. All elevations are referred to local datums. Other notes as in Fig. 2. 
Western Foothills. The fault thrusts Miocene or Pliocene sedimentary rocks on the hanging wall over Quaternary conglomerate on the footwall (Chang 1971), and appears to coincide with the mountain front that defines the western margin of the Taichung basin (Fig. 1). Farther east, these Mio-Pleistocene sequences are thrust over by Miocene strata along the TamaopuShuangtung fault (Fig. 1). The major ruptures ( $>0.2 \mathrm{~m}$ in slip) brought about by the Chi-Chi earthquake are all restricted west of this fault system.

The hill area where the anomalous Chi-Chi earthquake rupture (and uplift) crosses is mainly underlain by the Shihweichiang-Toukoushan syncline (hereafter the ST syncline) that trends in a north-south direction (Figs. 1 and 3). To the south, the ST syncline bounds on the Tamaopu-Shuangtung fault, and its westem limb continues as a monoclinal structure (Chang 1971) (Fig. 1). There are also two minor anticlines in the area: the Taan and Newan anticlines on the west and east of the axis of the ST syncline, respectively (Fig. 3; Torri 1934; Chinese Petroleum Corporation, 1974; Huang 1982; Lee 2000). Note that the uplift brought about by the Chi-Chi earthquake appears to follow the axial part of the Newan anticline as it extends from the Tachia to the Taan River valley (Fig. 3).

\subsection{Structures Around Shihgang of the Tachia River Valley}

We surveyed the lower Tachia River valley around Shihgang after the Chi-Chi earthquake and found a number of structures that are not shown on the published geological maps (e.g., Torri 1934; Chinese Petroleum Corporation 1974; Chang 1994; Lee 2000). We summarize these findings as follows (Fig. 4).

(1) The modern channel bed downstream from the Shihgang Dam well exposes the Cholan Formation (sandstone/shale), Chinshui Formation (shale) and Kueichulin Formation (sandstone/shale) in order (Fig. 4). We found that the Kueichulin and Chinshui Formations north of the valley appear to tum west and southwest in the valley, which is consistent with the southward plunge of the Taan anticline (Fig. 4). In addition, the earthquake rupture follows the bedding of the upper Chinshui Formation where it damaged the Pifeng Bridge across the main channel (Fig. 4). The sandstone and shale exposed on the valley wall south of the Pifeng Bridge were mapped as the Kueichulin and Chinshui Formations respectively on the published geological maps (e.g., Chinese Petroleum Corporation 1974). Our observation, however, prefers that both rocks should belong to the Cholan Formation, judging from the rock lithology and altitude exposed on the modem channel bed (Fig. 4).

(2) The strata west of Shiaolipu strike west and dip north, and are consistent with the orientation of the earthquake rupture/warping in the area (Fig. 4). The configuration of these strata suggests that the ST syncline north of the valley should plunge to the north (Fig. 4). In contrast, the ST synclinal south of the valley plunges to the south (Fig. 3; Chang 1971; Chinese Petroleum Corporation 1982).

(3) The earthquake rupture offsetting the main channel southwest of Shiaolipu follows a kinkfold hinge that separates the steeply inclined $\left(50^{\circ}\right)$ strata to the east from the gently inclined $\left(<15^{\circ}\right)$ strata to the west (Fig. 4).

(4) The east-west-trending earthquake rupture south of the Shihgang Dam coincides with a fault (dip $50-60^{\circ} \mathrm{N}$ ) that separates the steeply inclined (up to $70^{\circ}$ ) strata to the north from the 


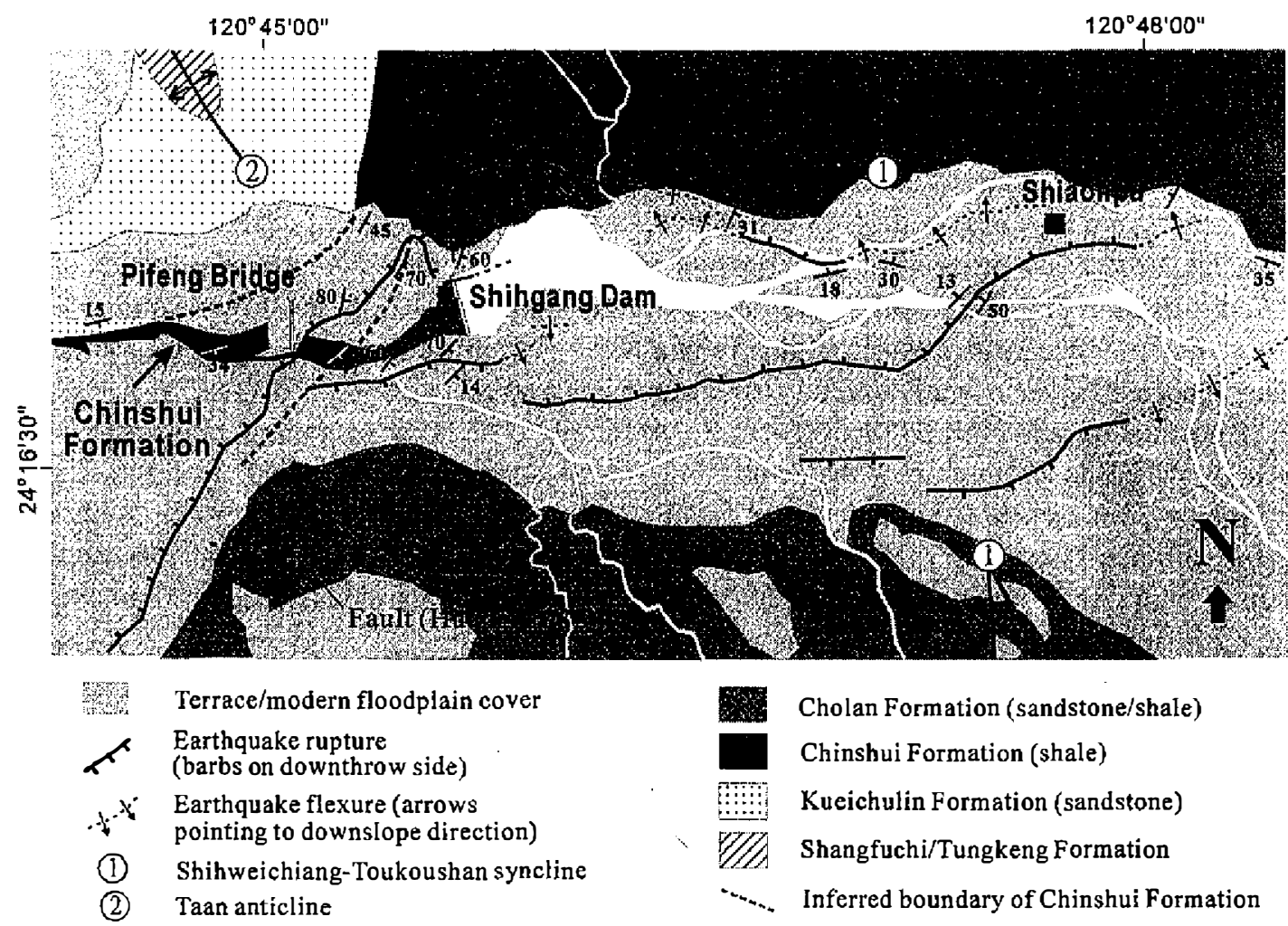

Fig. 4. Summary of the attitudes of the Mio-Pleistocene strata in the Tachia River valley surveyed in this study. For location see Fig. 3. The channel bed downstream from the Shihgang Dam shows the stratigraphic formations observed in this study. Based on this observation, the strata exposed on the valley wall south of the Shihgang Dam should belong to the Cholan Formation, although they were mapped as the Kueichulin and Chinshui Formations. Other notes as in Figs. 2 and 3.

gently inclined $\left(<20^{\circ}\right)$ strata to the south (Fig. 4). Unlike the fold hinge mentioned in (3), this fault is oriented obliquely to the strike of the strata (Fig. 4). This fault has about $0.7 \mathrm{~m}$ thick fault gouges and appears to have slipped prior to the earthquake.

In sum, the linkage of the strata and structures across the Tachia River valley could be more complicated than one might interpret from any published geological maps. The Taan anticline and the ST syncline north of the valley appear to die out rather sharply in the valley. In addition, there exists at least one east-west-mending fault in the valley. Such an east-westtrending fault in fact is not unique in the region. Chinese Petroleum Corporation (1974) has mapped one between the Tachia and the Taan river valleys, and another north of the Taan river valley (Fig. 3). Huang (1982) also interpreted two such faults south of the Tachia River valley (Fig. 4). These faults, however, only extend locally (Figs. 3 and 4). 


\section{GEOMORPHIC DATA}

\subsection{River Terraces Adjacent to the Mountain Front}

The portions of the mountain front north and south of the Tachia River valley appear to be connective in a regional scale (Figs. 1 and 2). We found, however, that the river terraces adjacent to these two portions of the mountain fronts have different characteristics, which may reflect different activities of the Chelungpu-Sanyi fault to the north and to the south. The mountain-front escarpment north of the Tachia River valley is composed of laterized gravel/ sand deposits that have been tilted to $>10^{\circ}$ (we do not map them on Fig. 2 because they do not show distinct terrace morphology on aerial photographs). This escarpment is bounded to the west by the broad Holi terrace (labeled HL; Fig. 2) that also has been laterized. In contrast, the mountain-front escarpment south of the Tachia River valley is cut locally by a non-laterized terrace remnant (labeled FY; Fig. 2) $50 \mathrm{~m}$ above the modern channel. To the west, this escarpment is bounded by the modern floodplain and some local non-laterized terraces $<10 \mathrm{~m}$ above the modern channel (Figs. 1 and 2).

The laterization of the mountain-front escarpment north of the Tachia River valley implies that this portion of the mountain front has been more stable than its counterpart to the south. Considering that the active movement of a mountain-front fault could steepen the mountain front and enhance erosion, the Chelungpu-Sanyi fault north of the Tachia River valley thus seems to have been less active than its counterpart to the south since at least the laterization of these landforms. In addition, the development of the laterized HL terrace indicates that the footwall area of the Chelungpu-Sanyi fault north of the Tachia River valley has been subject to a relatively slow uplift. In contrast, the Taichung basin to the south, which is mainly floored by the modern floodplain, appears to have been tectonically stable or undergone long-term subsidence. We believe that the formation of the Taichung basin, like other sedimentary basins around the world (e.g., Miall 1995), is related to the movement of its adjacent thrust fault. This again suggests that the Chelungpu-Sanyi fault south of the Tachia River valley has been more active in the recent geological time (cf. Chen et al. 2000).

\subsection{River Terraces in the Taan River Valley}

The lower Taan River valley is floored by a wide modern floodplain (maximum width of $3 \mathrm{~km}$ ) and terraces one to two steps in each cross section (Fig. 5). Two major tributaries, the Jingshan and Laochung rivers, flow approximately parallel to the valley and enter the valley with low angles (Figs. 2 and 5). Note that the lower portions of these two tributaries (with gradients of $<0.9 \times 10^{-2}$ for their lower $10 \mathrm{~km}$ ) are gentler than the trunk channel (and the modern floodplain) in the valley that has a gradient of $1.3 \times 10^{-2}$ (Table 1). As a result, the two wibutaries are lower than the trunk river in most sections normal to the valley (e.g., Fig. 5, Profile EE').

Laterized terraces. The major terrace remains in the lower Taan River valley, 80-180 m above the modern channel and as wide as $1 \mathrm{~km}$, are all laterized (Lin 1957) (Fig. 5). Limited exposures show that at least some of them consist of gravel beds thicker than $50 \mathrm{~m}$. We labeled these terraces $\mathrm{TA}_{\mathrm{a}}$ to $\mathrm{TA}_{\mathrm{e}}$ from downstream to upstream (Fig. 5). Terrace $\mathrm{TA}_{\mathrm{a}}$ is 


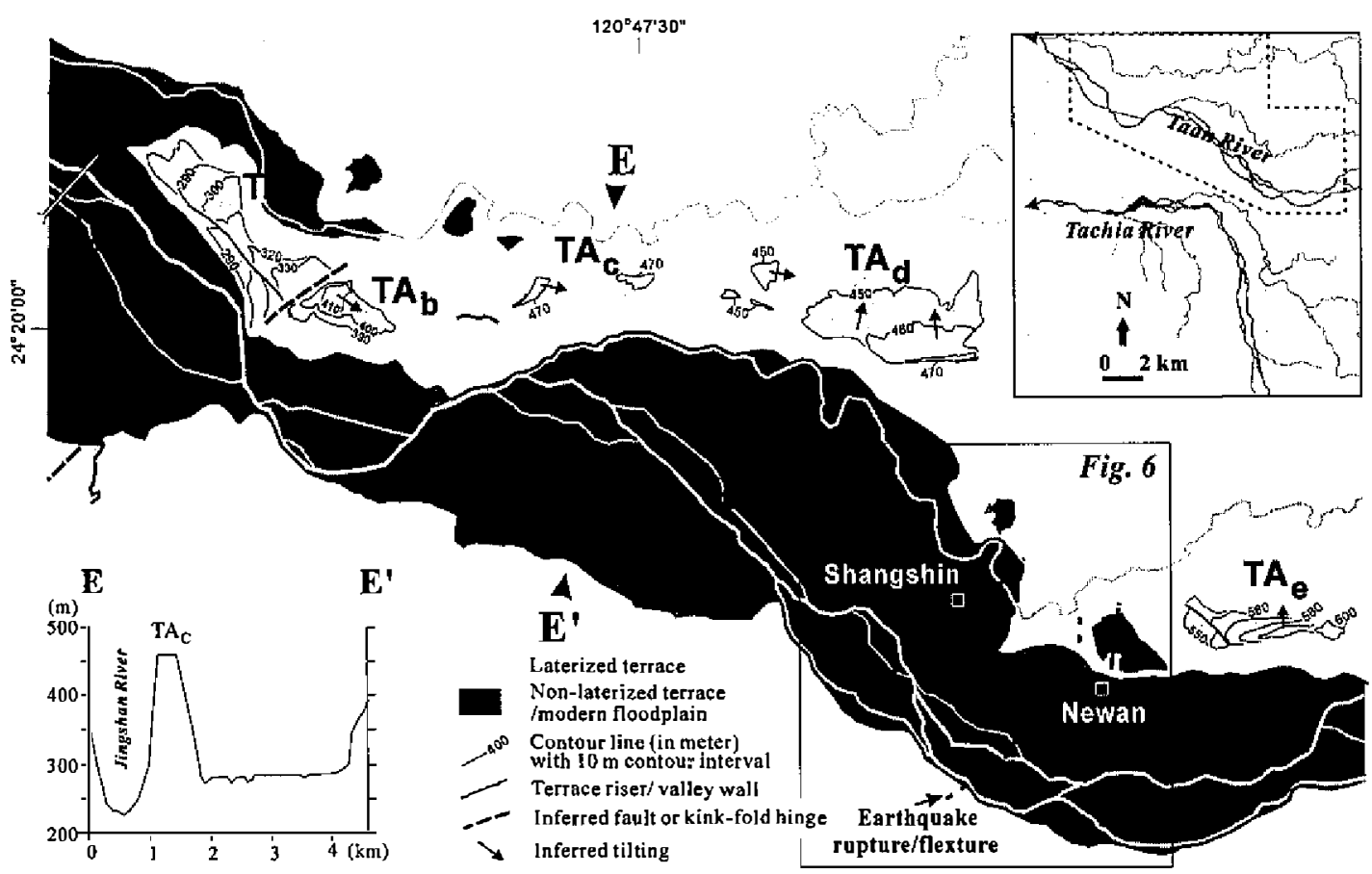

Fig. 5. Distribution and morphology (pre-earthquake) of the river terraces in the lower Taan River valley. Summarized from the 1-to-25000-scale topographic map issued in 1992.

separated from Terrace $T A_{b}$ by a linear escarpment $60 \mathrm{~m}$ in height (Fig. 5). We interpret this escarpment as of fault origin because it sharply offsets $<10 \mathrm{~m}$-high terrace risers on both terrace surfaces that appear to have been a continuous surface (Fig. 5). Only Terrace TA dips normally to the downstream direction. The other terrace surfaces incline either upstream ( $\mathrm{TA}_{b}$, $\mathrm{TA}_{\mathrm{c}}$ and $\mathrm{TA}_{\mathrm{d}}$ ) or toward the valley sides $\left(\mathrm{TA}_{\mathrm{d}}\right.$ and $\left.\mathrm{TA}_{\mathrm{c}}\right)$ (Fig. 5). We interpret that these abnormally dipping surfaces have been tilted after their abandonment. Based on the tilting directions, the structures likely have axes trending approximately parallel to the main valley for the $\mathrm{TA}_{d}$ and TA $\mathrm{e}_{e}$ surfaces, and oblique to the valley for the $\mathrm{TA}_{b}$ and $\mathrm{TA}_{c}$ surfaces (Fig. 5).

All these lateralized terraces are preserved (or developed) on the right (northern) bank of the modern floodplain (Figs. 2 and 5). In this bedrock-confined valley, this asymmetric terrace distribution requires that the channel belt migrated southward and progressively trimmed back the southern side of the valley wall. We found that the Taan River (and the Tachia River), dominated by braided channels and consisting of coarse gravel, does not provide processes that can shift itself to a preferred direction. In addition, we saw no tributary fans on the northern side of the valley, which might have swerved the trunk channel to the south. We thus interpret that this southward migration of the river reflects southward tilting, which is locally superimposed by the structures inferred from individual terraces shown above.

Non-laterized terraces. The major non-laterized terrace remains in the Taan River valley 
Table 1. Channel gradients of the Taan and Tachia rivers and their major tributaries.

\begin{tabular}{|l|c|l|}
\hline \multicolumn{1}{c|}{ River } & Gradient* $\left(\mathbf{1 0} \mathbf{0}^{-2}\right)$ & \multicolumn{1}{c|}{ note } \\
\hline Trunk Taan River & 1.30 & $\begin{array}{l}\text { From elevations } 170 \mathrm{~m}(0.5 \mathrm{~km} \text { upstream of the junction of the } \\
\text { Jingshan R. }) \text { to } 430 \mathrm{~m}(19.9 \mathrm{~km} \text { in length })\end{array}$ \\
\hline Jingshan River & 0.74 & From elevations $170 \mathrm{~m}$ to $300 \mathrm{~m}(17.6 \mathrm{~km}$ in length $)$ \\
\hline Laochung River & 0.87 & From elevations $280 \mathrm{~m}$ to $380 \mathrm{~m}(11.5 \mathrm{~km}$ in length $)$ \\
\hline Trunk Tachia River & 1.05 & $\begin{array}{l}\text { From elevations } 250 \mathrm{~m}(250 \mathrm{~m} \text { downstream of the Shihgang } \\
\text { inam) to } 430 \mathrm{~m}(17.2 \mathrm{~km} \text { in length })\end{array}$ \\
\hline Shalien River & 1.01 & From elevations $280 \mathrm{~m}$ to $380 \mathrm{~m}(9.9 \mathrm{~km}$ in length $)$ \\
\hline
\end{tabular}

* measured from 1-to-25000-scale topographic map issued in 1992.

are located between terraces $\mathrm{TA}_{\mathrm{d}}$ and TA $\mathrm{e}_{\mathrm{e}}$ (Fig. 5). The one north of Newan is crossed by a 15 m-high scarp that trends north-south (Figs. 5 and 6). We interpret this scarp as a fault- or foldscarp, because it perpendicularly runcates terrace risers and unlikely were created by fluvial processes (Figs. 5 and 6). Note that this inferred fault/fold scarp is only $400 \mathrm{~m}$ east of the ChiChi earthquake rupture that crosses the valley (Figs. 5 and 6).

A terrace (elevation 340-370 m; Fig. 6) $<10$ m higher than the modern floodplain also occurs around Shangshin where the Laochung River enters the valley (Figs. 5 and 6). This terrace is downcutted by the Laochung tributary by as much as $15 \mathrm{~m}$ and grades downstream to the modern floodplain. The shape of this surface (Fig. 6) suggests that it might have been a part of a local fan surface aggraded by the trunk river where the valley slightly widens around Shangshin (Figs. 5 and 6). Alternatively, the rise of this surface above the modern floodplain, together with another minor terrace (elevation 385-390 m) west of Newan (Figs. 5 and 6), may indicate that the area has been uplifted more rapidly than its adjacent river reaches, or has been domed. Note that the position of this possible doming is exactly where the valley was uplifted during the Chi-Chi earthquake (Figs. 5 and 6):

\subsection{River Terraces in the Tachia River Valley}

In contrast to the Taan River valley, the lower Tachia River valley is floored by a narrow modern floodplain (mostly $<1 \mathrm{~km}$ in width) and terraces with impressive heights and numbers of steps (Figs. 7 and 8). The modern trunk channel in this valley has a gradient of $1.05 \times 10^{-2}$, and is gentler than the channel in the lower Taan River valley (Table 1). This gradient is similar to that of the major ributary (the Sailien River; Fig. 2) in the valley, but is greater than the gradients of the lower Jingshan and Laochung rivers in the Taan River basin (Table 1). At least 13 steps of terrace remains can be distinguished in the lower Tachia River valley; we label them $\mathrm{TC}_{1}$ to $\mathrm{TC}_{13}$ basically from high to low above the modern channel (Fig. 7; Table 2). Terraces $\mathrm{TC}_{1}$ to $\mathrm{TC}_{8}$ are laterized; Terraces $\mathrm{TC}_{9}$ to $\mathrm{TC}_{13}$ are non-laterized (Fig. 7) (Lin 1957; $\mathrm{Ku}$ 1963; Shih et al. 1986; Chen et al. 2000).

Laterized terraces. The laterized terraces have heights ranging from $350 \mathrm{~m}$ (Terrace $\mathrm{TC}_{1}$ ) to $90 \mathrm{~m}$ (Terrace $\mathrm{TC}_{8}$ ) above the modern channel, and consist of gravel beds $20 \mathrm{~m}$ (Terrace $\mathrm{TC}_{8}$ ) to $>50 \mathrm{~m}$ (e.g., Terrace $\mathrm{TC}_{7}$ ) in thickness. Based on morphology and sequence of these 
terraces, several tectonic features have been inferred by Ku (1963) and Shih et al. (1986). They include (1) doming of Terraces $\mathrm{TC}_{1}$ and $\mathrm{TC}_{5}$ (Shih et al. 1986); (2) faulting across Terrace $\mathrm{TC}_{5}$ (named Gunglaoping; Shih et al. 1986); (3) faulting separating Terraces $\mathrm{TC}_{1} / \mathrm{TC}_{3}{ }^{\prime}$ $\mathrm{TC}_{4 \mathrm{~b}} / \mathrm{TC}_{6 \mathrm{~b}}$ from $\mathrm{TC}_{7} / \mathrm{TC}_{8}$ (named Hsinshe; Ku 1963); (4) faulting separating Terraces $\mathrm{TC}_{2}$ ' $\mathrm{TC}_{4 \mathrm{a}} / \mathrm{TC}_{6 \mathrm{a}}$ from $\mathrm{TC}_{3} / \mathrm{TC}_{4 \mathrm{~b}} / \mathrm{TC}_{6 \mathrm{~b}}$ (also named Hsinshe; Shih et al. 1986) (Fig. 7).

In addition to these structures, we found that Terraces $\mathrm{TC}_{7}$ and $\mathrm{TC}_{8}$ have been tilted to the

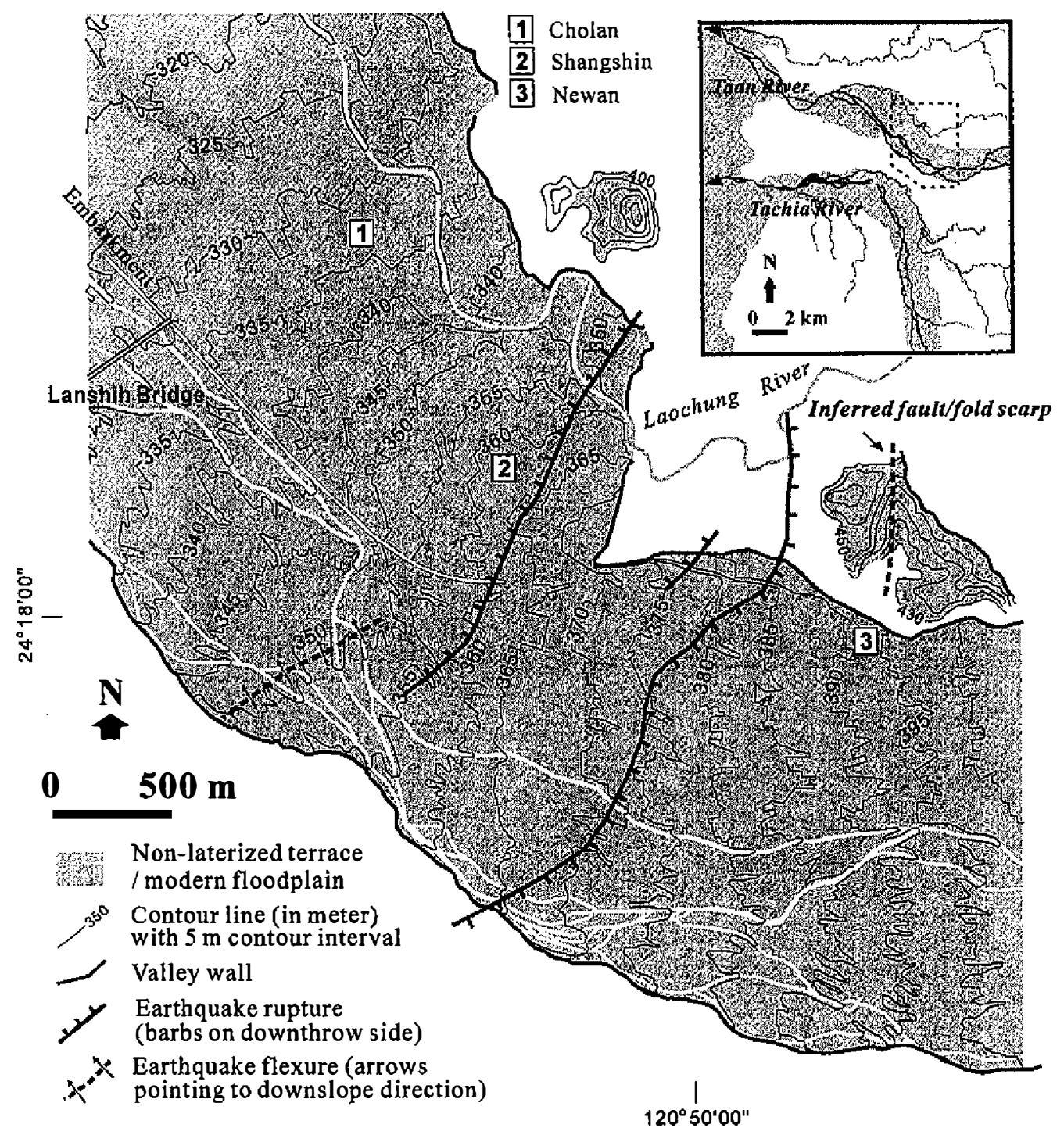

Fig. 6. Overlay of the pre-earthquake morphology of the modern floodplain/ non-laterized terraces around Cholan-Newan with the Chi-Chi earthquake ruptures/flexures. For location see Fig. 5. Contour lines after the 1-to5000-scale topographic map issued in 1979. Other notes as in Fig. 2. 


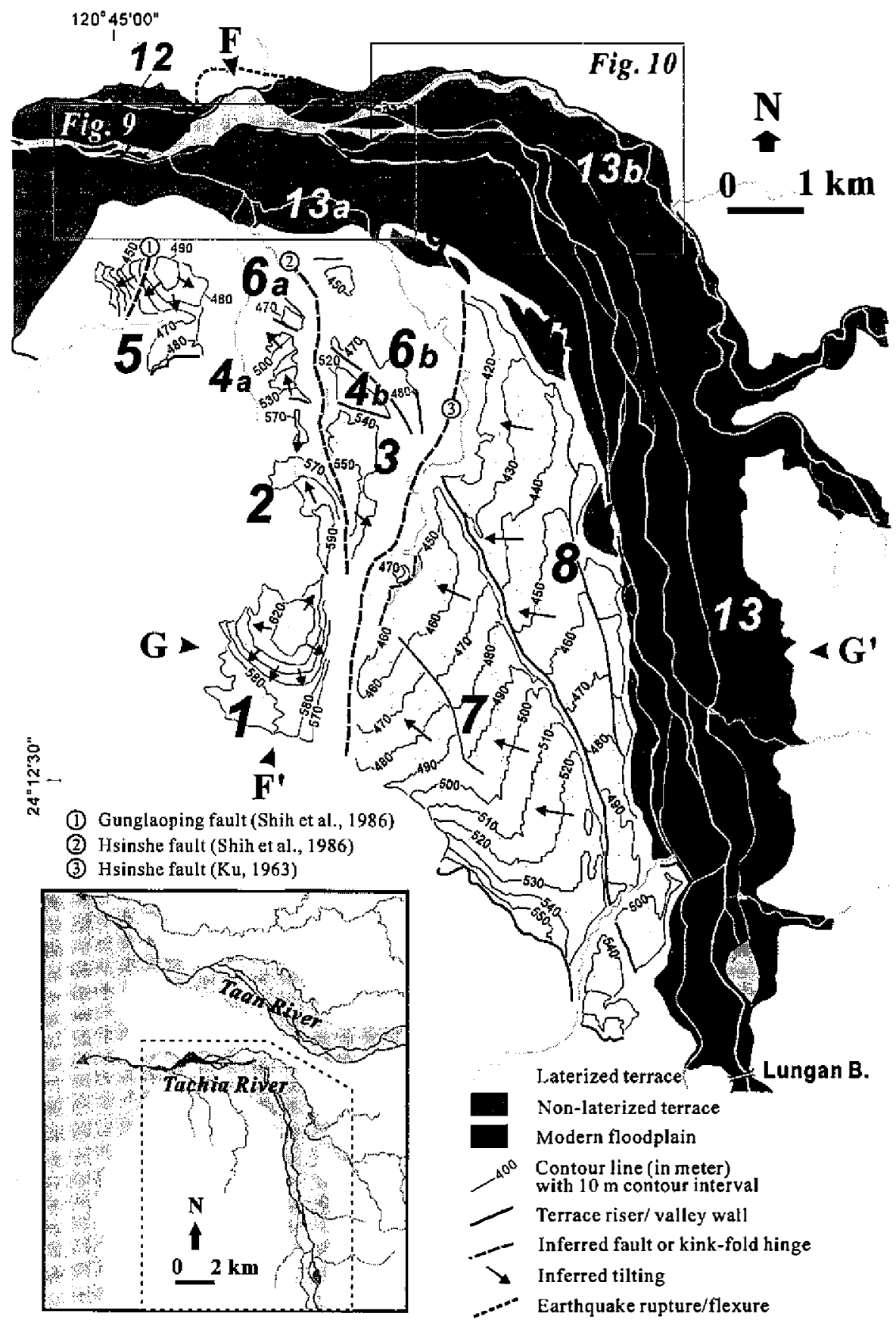

Fig. 7. Distribution and morphology (pre-earthquake) of the river terraces in the lower Tachia River valley. Summarized from the 1-to-25000-scale topographic map issued in 1992. Capital TC in each terrace label (bold italic) is omitted for simplicity. 

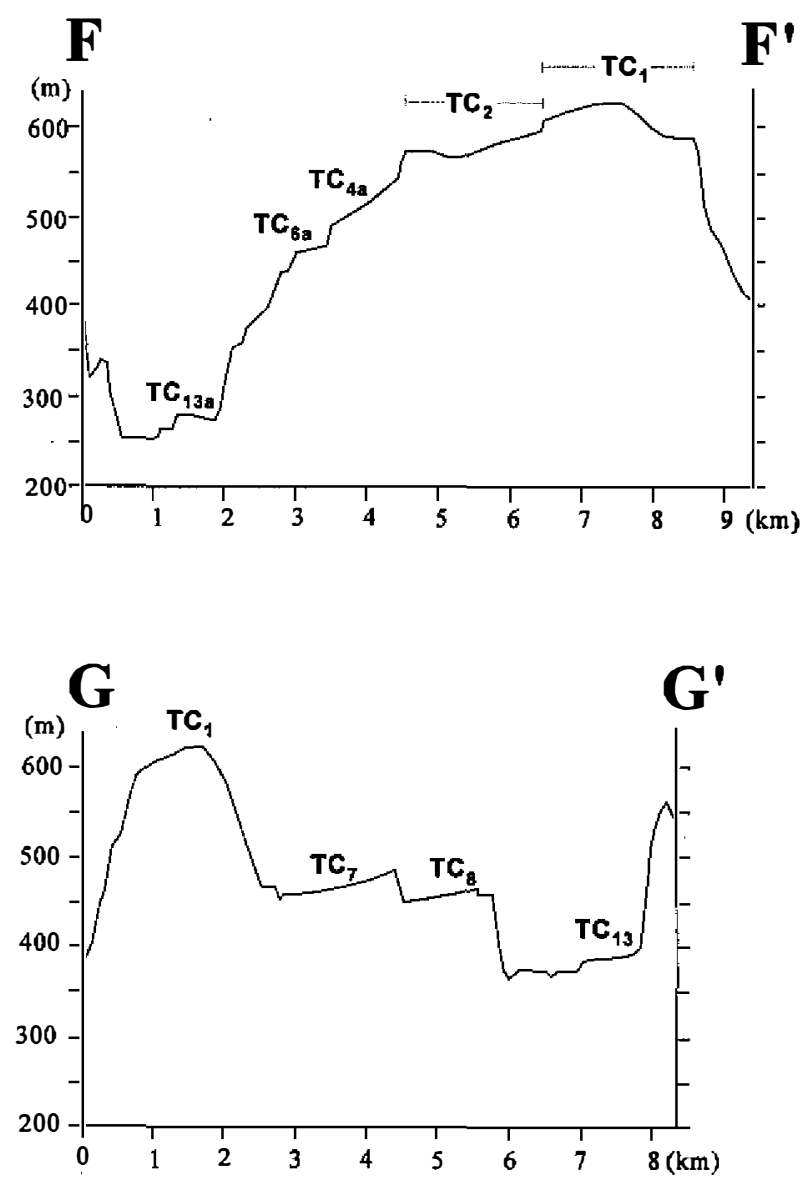

Fig. 8. Cross profiles of the Tachia river valleys (for locations see Fig. 7). Profile FF' is mainly along the dips of terrace surfaces; $\mathrm{GG}^{\prime}$ is along a straight line.

west (Fig. 7). The two terraces, the most extensive ones in the region, incline prevailingly to the west (except for local fans on the southern edge of the $\mathrm{TC}_{\text {? }}$ terrace), which is $>45^{\circ}$ oblique to the straight terrace riser between the two terraces (Fig. 7). This terrace riser, presumably created synchronously with the $\mathrm{TC}_{8}$ terrace surface, should trend parallel to the dip of the $\mathrm{TC}_{8}$ terrace, unless the whole terrace has been tilted. The $\mathrm{TC}_{7}$ terrace also is steeper than the $\mathrm{TC}_{8}$ (Figs. 7 and 8; profile GG'), which suggests that the tilting has proceeded since the abandonment of the $\mathrm{TC}_{7}$ terrace.

The westward incline of the $\mathrm{TC}_{7}$ terrace terminates near the western edge of the terrace. Here, a scarp occurs separating the west-dipping $\mathrm{TC}_{7}$ terrace to the east from a minor surface 10-20 $\mathrm{m}$ higher to the west (Fig. 7). This scarp was unlikely eroded by the trunk Tachia River channel, which, as shown by the nearby terrace risers, flowed significantly obliquely to this scarp (Fig. 7). We thus interpret that this scarp was originated by faulting or kink folding (Fig. 7). This inferred fault- or fold-scarp is parallel to the Hsinshe fault of Ku (1963) (Fig. 7). The Hsinshe fault of $\mathrm{Ku}$ (1963) also is a boundary between much of the west-dipping $\mathrm{TC}_{7} / \mathrm{TC}_{8}$ terraces and the $\mathrm{TC}_{1} / \mathrm{TC}_{3} / \mathrm{TC}_{4 \mathrm{a}} / \mathrm{TC}_{6 \mathrm{~b}}$ that do not appear to have been westerly tilted (parts of the $\mathrm{TC}_{1}$ and $\mathrm{TC}_{3}$ even incline to the east) (Fig. 7). This implies that the Hsinshe fault of Ku (1963) 
Table 2. Labeled river terraces in the Tachia River valley and their equivalent names.

\begin{tabular}{|c|c|c|c|}
\hline This study* & Lin $(1957)$ & Shih et al. (1986) & Chen et al. (2000) \\
\hline $\mathrm{TC}_{1}$ & \multirow[t]{2}{*}{ Shuijingtz (LH) } & Shuijingtz (LH), Yungyuan (LF, & \multirow[t]{2}{*}{ Lt5 } \\
\hline $\mathrm{TC}_{2}$ & & Kengtou $\left(\mathrm{LT}_{1}\right)$ & \\
\hline $\mathrm{TC}_{3}$ & Chifen (LT) & Chifen $\left(\mathrm{LT}_{1}\right)$ & Lt4 \\
\hline $\mathrm{TC}_{4 \mathrm{a}}$ & Shangweijinshing $\left(\mathrm{LT}_{2}\right)$ & Shangweijinshing $\left(\mathrm{LT}_{2}\right)$ & \multirow[t]{2}{*}{ Lt3 } \\
\hline $\mathrm{TC}_{4 \mathrm{~b}}$ & Shihfen $\left(\mathrm{LT}_{2}\right)$ & Shihfen $\left(\mathrm{LT}_{2}\right)$ & \\
\hline $\mathrm{TC}_{5}$ & Gunglaoping $\left(\mathrm{LT}_{2}\right)$ & Gunglaoping ( $\mathrm{LT}_{2}$ ) & Lt4 \\
\hline $\mathrm{TC}_{6 \mathrm{a}}$ & Shiaweijinshing $\left(\mathrm{LT}_{3}\right)$ & Shiaweijinshing $\left(\mathrm{LT}_{3}\right)$ & \multirow[t]{2}{*}{ Lt3 } \\
\hline $\mathrm{TC}_{6 \mathrm{~b}}$ & Shientangping $\left(\mathrm{LT}_{3}\right)$ & Shientangping ( $\left(\mathrm{LT}_{3}\right)$ & \\
\hline $\mathrm{TC}_{7}$ & Danan (LT & Danan $\left(\mathrm{LT}_{4}\right)$ & $\mathrm{Lt} 2 / \mathrm{Lt} 3$ \\
\hline $\mathrm{TC}_{8}$ & Shuidiliao $\left(\mathrm{LT}_{5}\right)$ & Shuidiliao $\left(\mathrm{LT}_{5}\right)$ & Ltl \\
\hline $\mathrm{TC}_{9}$ & -- & Shihgang Junior High School (FT $)$ & -- \\
\hline $\mathrm{TC}_{10}$ & Yungiuhu $\left(\mathrm{FT}_{1}\right)$ & Yuehu $\left(\mathrm{FT}_{1}\right)$ & \multirow{3}{*}{ Ft3 } \\
\hline $\mathrm{TC}_{31}$ & Nanmei $\left(\mathrm{FT}_{\mathrm{l}}\right)$ & Nanmei $\left(\mathrm{FT}_{1}\right)$ & \\
\hline $\mathrm{TC}_{12}$ & - & - & \\
\hline $\mathrm{TC}_{13}$ & Tuniu $\left(\mathrm{FT}_{3}\right)$ & Shihgang $\left(\mathrm{FT}_{2}\right)$, Tuniu $\left(\mathrm{FT}_{3}\right)$ & $\mathrm{Ft} 1 / \mathrm{Ft} 2$ \\
\hline
\end{tabular}

* This labeling is only for the convenience of spatial identification and has no chronological connotation.

is located on the hinge zone of a fold (or the "fault" itself is a fold-hinge; Suppe et al. 2000).

All laterized terraces in the lower Tachia River valley (and non-laterized terraces $\mathrm{TC}_{9}$ to $\mathrm{TC}_{11}$ ) are developed on the left bank of the modern floodplain (Figs. 2 and 7) (Lin 1957; Ku 1963; Shih et al. 1986). They generally step down toward both the north and east (Fig. 8, profiles FF' and GG'), showing long-term northward and eastward migration of the river (Ku 1963; Shih et al. 1986). We interpret this as a result of regional tilting-perhaps a part of north-south-trending doming that plunges to the north.

Non-laterized terraces. The non-laterized terraces $\left(\mathrm{TC}_{9}\right.$ to $\left.\mathrm{TC}_{13}\right)$ are much lower and/or local (Fig. 7) and have thinner terrace deposits ( $<20 \mathrm{~m}$ to a few meters thick) than the laterized terraces. These terraces have heights of $80 \mathrm{~m}\left(\mathrm{TC}_{9}\right)$ to $5 \mathrm{~m}$ above the modern channel. Terraces with heights of $30-5 \mathrm{~m}$ above the modern channel in fact have multiple steps. They are however too complex in sequence to be correlated along the valley, and we temporarily group and label them $\mathrm{TC}_{13}$ (Fig. 7). Terraces $\mathrm{TC}_{13}$ and $\mathrm{TC}_{12}$ have weakly developed soil horizons, and thus likely were abandoned during the Holocene.

Most of the Chi-Chi earthquake ruptures in the Tachia River valley cross Terrace $\mathrm{TC}_{13}$ (Fig. 7). We focus on two $\mathrm{TC}_{13}$ terraces, one around Shihgang $\left(\mathrm{TC}_{13 \mathrm{a}}\right)$ and the other around Shiaolipu $\left(\mathrm{TC}_{13 \mathrm{~b}}\right.$ ) (Figs. 7, 9 and 10), which have morphology that may suggest tectonic deformation prior to the earthquake. The $\mathrm{TC}_{13 \mathrm{a}}$ terrace, as high as $30 \mathrm{~m}$ above the modern channel, grades downs ream and merges with the modern floodplain in the Taichung Basin. The most northern part of this terrace is $<5 \mathrm{~m}$ higher than the rest of the terrace from elevations $255 \mathrm{~m}$ to $300 \mathrm{~m}$ (except for an alluvial fan to the south), especially in the area south of the Pifeng Bridge and the area between elevations $285 \mathrm{~m}$ and $300 \mathrm{~m}$ (cf. Chen et al. 2000) (Fig. 9a). Note however that this inclination is local and gentle, and not as obvious as that shown on the 

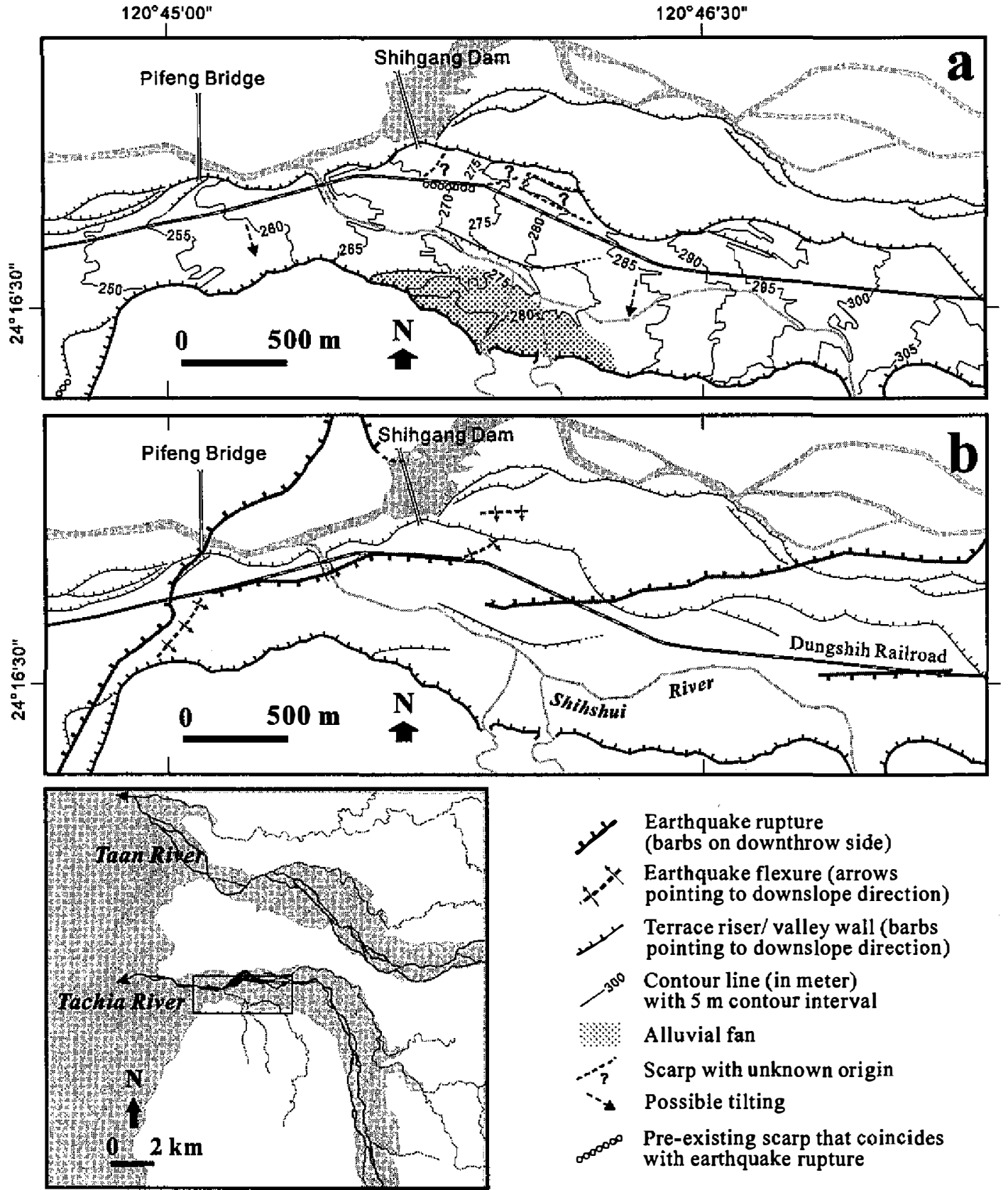

Earthquake rupture

(barbs on downthrow side)

Earthquake flexure (arrows pointing to downslope direction)

Terrace riser/ valley wall (barbs pointing to downslope direction)

Contour line (in meter) with $5 \mathrm{~m}$ contour interval

\section{Alluvial fan}

$\ldots$ Scarp with unknown origin

$\because \quad$ Possible tilting

Pre-existing scarp that coincides with earthquake rupture

Fig. 9. Pre-earthquake morphology of the $\mathrm{TC}_{13 \mathrm{a}}$ terrace (contoured) in the Tachia River valley (9a), and the Chi-Chi earthquake ruptures/flexures that cross the terrace (9b). For location see Fig. 7. Contour lines after the 1-to5000-scale topographic map issued in 1979. Other notes as in Fig. 2. 


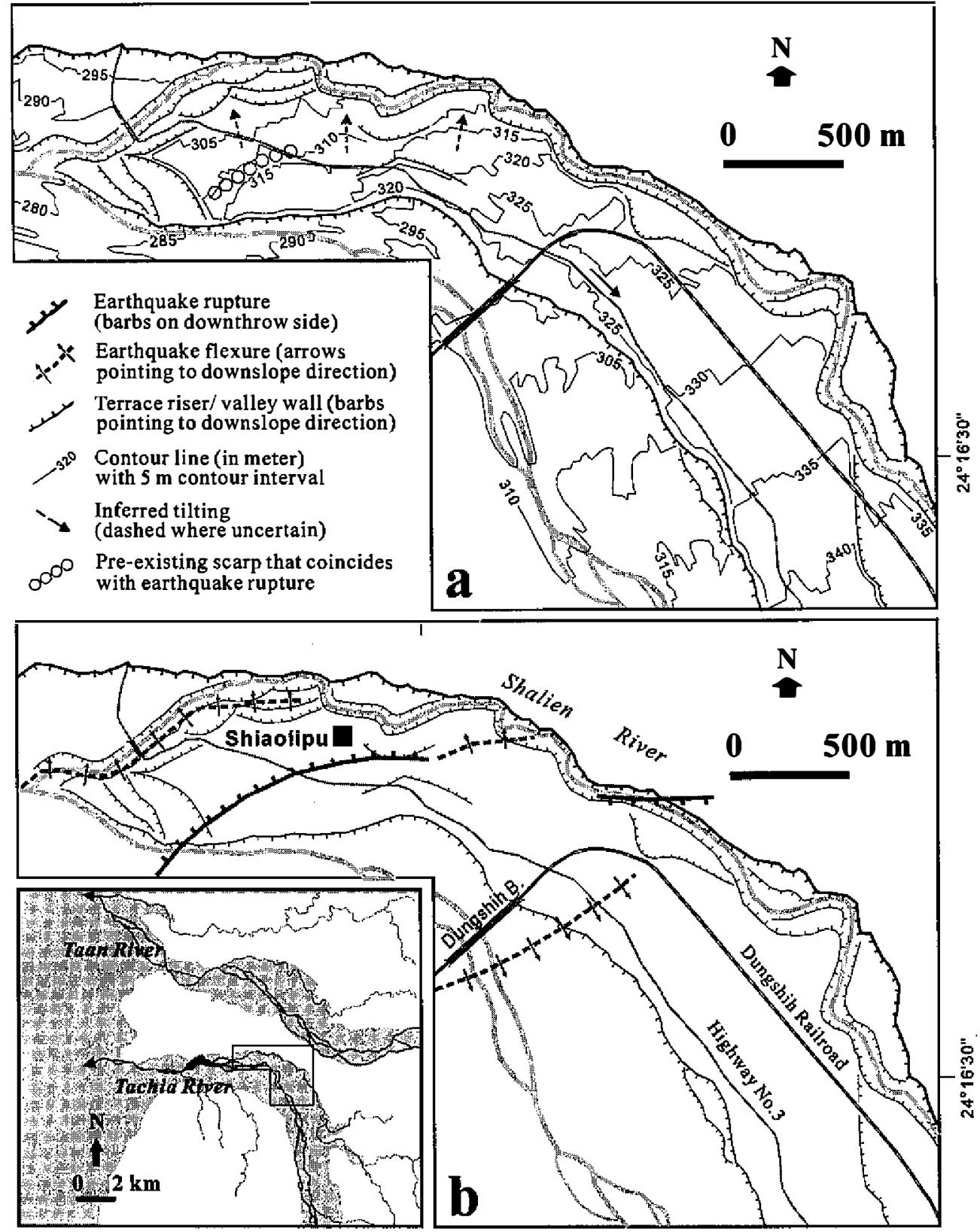

Fig. 10. Pre-earthquake morphology of the $\mathrm{TC}_{13 \mathrm{~b}}$ terrace and the modern floodplain (contoured) in the Tachia River valley (10a), and the Chi-Chi earthquake ruptures/flexures that cross the valley (10b). For location see Fig. 7. Contour lines after the 1-to-5000-scale topographic map issued in 1979. Other notes as in Fig. 2. 


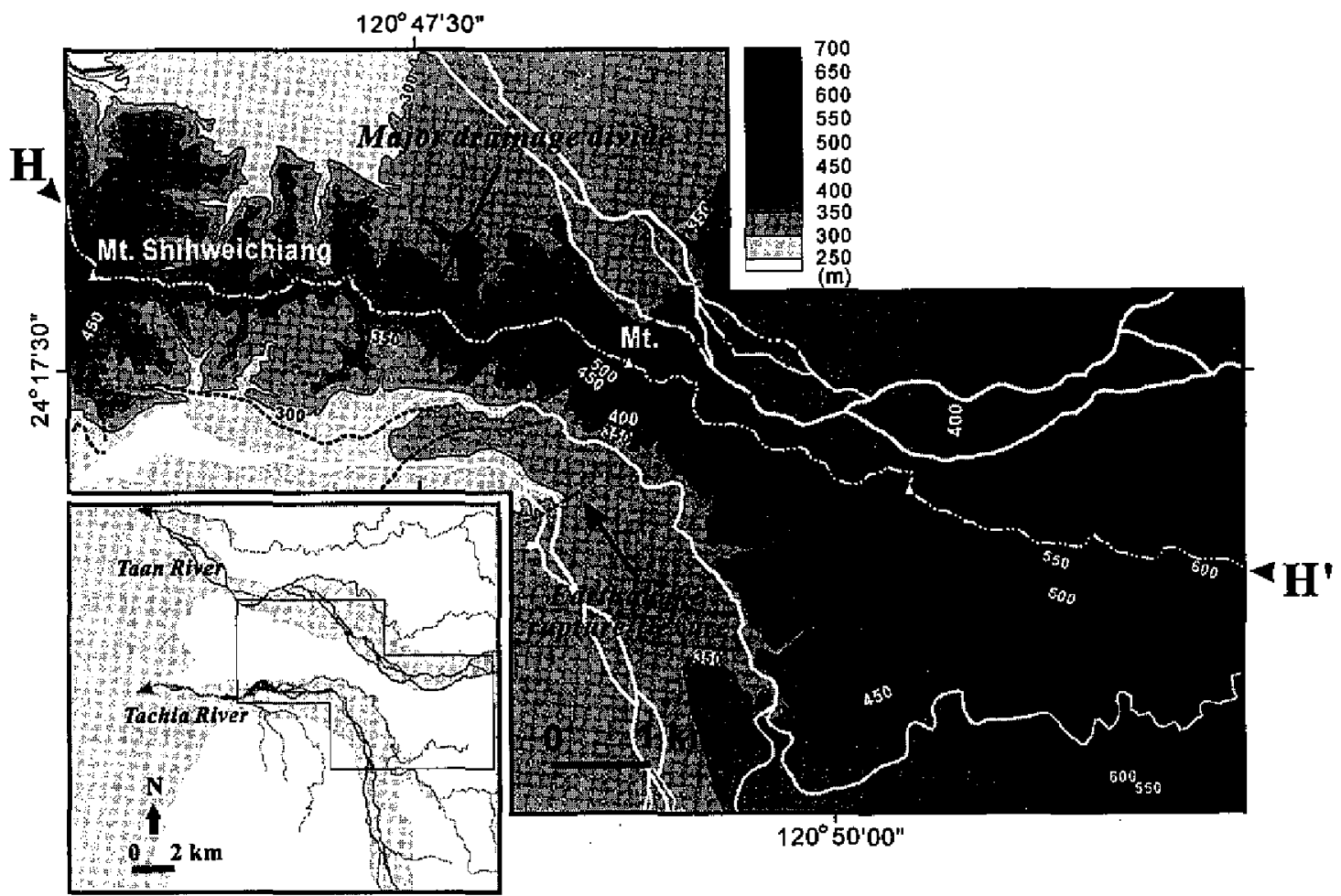

$\mathbf{H}$

H'

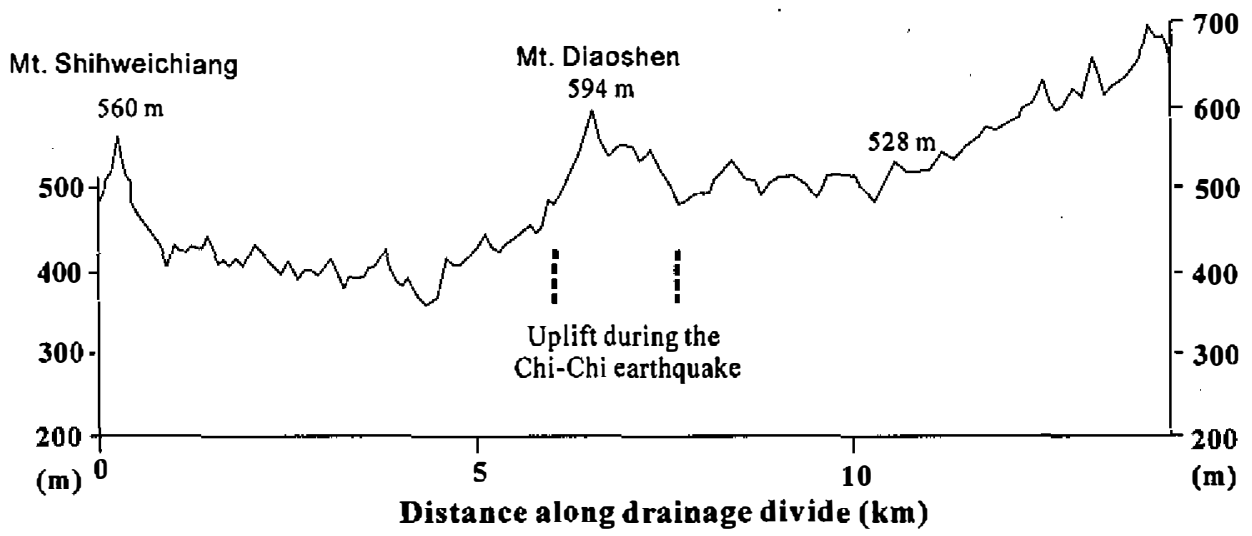

Fig. 11. Pre-earthquake morphology of the mountain range between the lower Taan and Tachia river valleys. Summarized from the 1-to-25000-scale topographic map issued in 1992. 
laterized terraces. It is also arguable whether this possible inclination is a result of tilting or caused by erosion of the Shihshui tributary (Fig. 9). Nonetheless, the overall morphology of the $\mathrm{TC}_{13 \mathrm{a}}$ terrace is consistent with the uplift brought about by the Chi-Chi earthquake, which generally tilted the area to the south (Figs. 3 and 9; profile $\mathrm{AA}^{\prime}$ and $\mathrm{BB}^{\prime}$ ). South of the Shihgang Dam, one portion of the earthquake rupture also coincides with a pre-existing, eastwest-trending scarp on the terrace (Fig. 9). This scarp appears to connect to the fault we observed nearby (Fig. 4), and thus likely is a fault-scarp.

Opposite to the $\mathrm{TC}_{13 \mathrm{a}}$ terrace, the $\mathrm{TC}_{13 \mathrm{~b}}$ terrace appears to incline to the north (Fig. 10a). Like the $\mathrm{TC}_{13 \mathrm{a}}$ terrace, whether this "inclination" results from tilting or progressive erosion of the Shalien tributary is arguable. Nonetheless, this "inclination" is consistent with the regionally northward tilting of the area during the Chi-Chi earthquake (Figs. 3 and 10; profile CC'). West of Shiaolipu, one portion of the earthquake rupture follows a pre-existing scarp on the terrace (Fig. 10). This scarp connects to the kink-fold hinge we observed nearby (Fig. 4), and likely is a fold-scarp (Lee et al. 2000; Suppe et al. 2000). The $\mathrm{TC}_{13 \mathrm{~b}}$ terrace east of the Dungshih Bridge also abnormally flattens downstream (as shown by the significantly larger spacing of the 325-330 m-contour lines in Fig. 10a). Seemingly, the terrace has been tilted to the upstream direction (Fig. 10a). Note that the location of this inferred tilting well matches with where the area was upstream tilted during the earthquake (Fig. 10).

The Chi-Chi earthquake also ruptured the $\mathrm{TC}_{12}$ terrace and the modern floodplain (Fig. 7). We however do not recognize any pre-existing fault/fold scarps on these surfaces.

\subsection{Drainage-divide Anomaly}

Other things being equal, the height of a mountain range is expected to be positively related to the width of the range (e.g., Koons 1995). This is especially true where retreat of range sides by fluvial erosion creates steeper hill slopes, which enhances erosion and further lowers the range. The mountain range between the lower Taan and Tachia river valleys, however, shows morphology that is opposite to this norm. The major drainage divide of the range is around $420 \mathrm{~m}$ in elevation east from Mt. Shihweichiang, and rises rather abruptly to > $550 \mathrm{~m}$ in elevation around Mt. Diaoshen (peak elevation: $594 \mathrm{~m}$ ) (Fig. 11; profile HH'). The Diaoshen Mountain is located where the range significantly narrows (Fig. 11). In addition, the cross-range section between Mt. Diaoshen and Mt. 528 is very asymmetric: the northern slope that faces the Taan River is much narrower and steeper than the southern slope that faces the Tachia River (Fig. 11). This implies that the Taan River channel around Shangshin and Newan has actively migrated southward and rimmed back the northern slope of the range (Figs. 6 and 11).

We did not find significant change in bedrock lithology (the Cholan Formation) along where the mountain range changes elevation and width. The abnormal higher elevation of the Diaoshen Mountain area thus requires that it has uplifted more rapidly than its counterpart to the west, assuming that the whole range has the same initial height and duration of uplift. Coincidentally, the area around the Diaoshen Mountain was uplifted during the Chi-Chi earthquake (Fig. 11). 


\section{DISCUSSION}

\subsection{Contrast in Neotectonics in the Taan and Tachia River Valleys}

The lower Tachia and Taan river valleys apparently have different morphology. The Tachia River consists of much higher and more levels of terraces (both laterized and nonlaterized) than the Taan River, which implies that the Tachia River long term has a higher tendency to incise than the Taan River (Chen et al. 2000). We attribute this contrast, at least in part, to more active uplift of the Tachia than the Taan river valleys. This interpretation is consistent with the apparent more active movement of the Chelungpu-Sanyi fault south of the Tachia River valley, based on the degree of laterization of the terraces and escarpments adjacent to the faults (Chen et al. 2000). Terraces that are capped by laterized soil horizons in Taiwan likely were abandoned earlier than $30 \mathrm{ka}$, according to available dating data (Chen and Liu 1991; Huang et al. 1993; our unpublished data). The tectonic features inferred above thus likely have proceeded since at least a few ten thousands of years ago. Consistently, the rock uplift brought about by the Chi-Chi earthquake is greater in the Tachia than in the Taan river valleys.

The significantly higher gradient of the modem Taan River channel than the Tachia River channel (Table 1) has led Lin (1953) to interpret that the Taan River valley has uplifted (tilted) more rapidly than the Tachia River valley. We however argue that the present higher gradient of the Taan River channel could be mainly due to the more abundant sediments it carries. This is because, first, rivers with sufficient energy usually have ability to incise and maintain constant gradients in response to tectonic uplift (e.g., Pazzaglia et al. 1998; Leland et al. 1998; Bull 1991), unless being perturbed by excess sediment supply (e.g., Bull 1991). It is arguable that the trunk Taan River, a high-energy river, can progressively steepen without extra sediments to balance the stream power gained by the steepening. Second, it would be difficult to explain why the tilting, if any, only has steepened the trunk Taan River channel, but not the Jingshan and Laochung tributaries that flow parallel to the main valley. The lower gradient of these two tributaries than the trunk river is atypical. We interpret that this is because these two tributaries do not drain $3000 \mathrm{~m}$-high mountain areas and therefore carry fewer and/or finer sediments than the trunk river. Of course, this lower gradient also requires that the main valley, which serves as local base levels of the tributaries, did not incise for a considerable time.

The lower Tachia and Taan river valleys also have different structures recorded by the river terraces. The structures inferred from the laterized terraces are mainly north-south/northeast-southwest oriented in the Tachia River valley (e.g., the Gunglaoping and Hsinshe faults; Fig. 7), but half of those are east-west oriented in the Taan River valley (Fig. 5). The structures infer from the $\mathrm{TC}_{13}$ terrace appear to strike east-west (Figs. 9 and 10), but the fault/fold scarp offsetting the non-laterized terrace near Newan is north-south oriented (Figs. 5 and 6). Furthermore, the overall lower Taan River valley likely has been tilted to the south, but the Tachia River valley been tilted to the north and east. It is unclear how these structures, with spatial and temporal variation of orientations, connect to each other from the one river valley to the other. Note, however, the trend of the Chi-Chi earthquake rupture is consistent with the 
trend of the structures inferred from the non-laterized terraces in both river valleys.

\subsection{Pre-locating the Chi-Chi Earthquake}

The lower Tachia and Taan river basins appear to have different neotectonic characteristics. This is consistent with the deformational pattern of the Chi-Chi earthquake and prompts the hope that the northeastern turn and the location of the earthquake rupture (and uplift) might have been predictable. Other lines of evidence that are positive for this prediction include:

(1) The Taan and Newan anticlines plunge toward the Tachia River valley. In addition, the ST syncline north of the Tachia River valley unlikely connects to the ST syncline south of the valley. These facts suggest that the lower Tachia River valley may be itself a kind of geological boundary (cf. Chen et al. 2000).

(2) The earthquake rupture follows the foot of the straight mountain-front escarpment between Fengyuan and the Tachia River valley.

(3) Portions of the Chi-Chi earthquake rupture follow pre-existing fault- or fold-scarps on the non-laterized terraces in the Tachia River valley. The coseismic warping or tilting also is consistent with the abnormal sideward inclination or downstream flattening of the nonlaterized terraces in the valley.

(4) The coseismic uplift across the Taan River valley coincides with where the valley locally develops low-level terraces.

(5) The coseismic uplift across the mountain range between the Taan and Tachia river valleys (around Mt. Diaoshen) coincides with the Newan anticline in position, and is consistent with where the range appears to have uplifted more rapidly, as suggested by the abnormal rising and narrowing of the range.

We argue, still, that the data above are insufficient for pre-locating most of the Chi-Chi earthquake rupture. First, most of the data tell little about potential earthquake ruptures in detail. We did not find any major fault systems (i.e., those with vertical separation as great as the Chelungpu-Sanyi fault) in the lower Tachia River valley, although the valley may be a kind of tectonic (or neotectonic) boundary. In fact, only two small portions of the Chi-Chi earthquake ruptures coincide with pre-existing fault/fold-scarps on the terraces in the valley; both scarps are indistinct and local compared with surrounding terrace risers (Figs. 9 and 10).

Second, the interpretation of some of the geomorphic features may not be unique. The mountain-front escarpment between Fengyuan and the Tachia River valley is oblique to the axis of the Tachia River valley (Fig. 2). It would have been equally reasonable to interpret this escarpment as a result of erosion by the Tachia River channel. Similarly, the sideward inclination of the non-laterized $\left(\mathrm{TC}_{13}\right)$ terraces in the Tachia River valley is indistinct and might have been interpreted as of fluvial origin. The development of the low-level terraces in the Taan River valley might have been linked to local aggradation of the valley. The more rapid uplift of the Diaoshen Mountain is perhaps the most convincing evidence. However, we would have had no confidence until the Chi-Chi earthquake that this tectonic feature still proceeded in the short past.

Third, there do exist a certain neotectonic features that are inconsistent with the deformation of the Chi-Chi earthquake. The $\mathrm{TC}_{13 \mathrm{a}}$ terrace in the Tachia River valley grades down- 
stream onto the modern floodplain. The abandonment of this terrace thus is more likely caused by regional tilting or warping than by faulting across itself as occurring during the earthquake. Similarly, the abandonment of the $\mathrm{TC}_{12}$ terrace requires faulting or warping downstream of the terrace, which is different from the rupture that off set the terrace during the earthquake.

Fourth, the link between our observed neotectonic features and the movement of the Chelungpu-Sanyi fault might have been unclear. Our data show that in the studied mountainfront area, the earthquake rupture is located within the upper Chinshui Formation (Fig. 4), and deviates from the traditionally defined Chelungpu-Sanyi fault by Chang (1971) and Meng (1963). We thus would have had no confidence to predict this portion of the rupture unless we had foreseen in what stratigraphic position an earthquake rupture initiated from the ChelungpuSanyi fault to the south might propagate to the north. It follows that our observed neotectonic features in the hills might have been interpreted as connected to other structural systems. For example, the Newan anticline that underlies the Diaoshen Mountain plunges to the south (Fig. 3). The southward migration of the Taan River channel that had trimmed back the northern slope of the Diaoshen mountain also may reflect southward tilting of the valley. The uplift of this mountain thus might have been linked to earthquakes generated by structures to the north, not by the Chelungpu-Sanyi fault to the south.

In short, we argue that the prediction of the northeastern tum and the location of the ChiChi earthquake rupture would have been difficult. Even after the earthquake when the origin of some of the geomorphic anomalies became clear, we could have at best used them to roughly delineate a potential coseismic deformational zone. Note that the structures shown on the studied non-laterized terraces are inconsistent with those shown on the laterized terraces, but have trends similar to those of the Chi-Chi earthquake rupture (and uplift) (Figs. 5, 7, 9 and 10). This implies that the region's tectonic pattern may have changed during the past ten thousands of years, and the current tectonic condition that is responsible for the earthquake may only proceed shortly (cf. Chen et al. 2000). We suspect that this may be the reason why the region lacks a discrete topographic boundary along which the earthquake rupture followed.

\section{CONCLUSIONS AND IMPLICATIONS}

We did not find any major fault systems in the studied hill area. Still, we recognized a certain pre-existing landscape anomalies and their inferred neotectonic stuctures that are consistent with the deformation brought about by the Chi-Chi earthquake. These geomorphic and structural features include:

(1) The lower Tachia river valley has uplifted more rapidly than the lower Taan River valley.

(2) The Chelungpu-Sanyi fault south of the Tachia River valley has been more active than its counterpart to the north.

(3) The earthquake rupture follows the foot of the straight mountain-front escarpment between Fengyuan and the Tachia River valley.

(4) There are portions of the earthquake rupture that coincide with two local pre-existing fault' fold-scarps on the non-laterized terraces in the Tachia River valley.

(5) The coseismic tilting or warping in the Tachia River valley is consistent with where the non-laterized terrace abnormally inclines to the valley side or flattens downstream. 
(6) The coseismic uplift in the Taan River valley coincides with where the valley developed major non-laterized terraces.

(7) The coseismic uplift crossing the Taan/Tachia drainage divide coincides with where the divide abnormally rises and narrows around the Diaoshen Mountain.

Except for (3) and (4), these geomorphic features tell little about the exact position of potential earthquake ruptures. Features (3), (5) and (6) might have been interpreted as of fluvial origin. Also, the link between these features and the movement of the ChelungpuSanyi fault to the south might have been uncertain. Furthermore, the downstream convergence of the non-laterized terraces in the lower Tachia River valley suggests that the valley has been characterized by regional tilting or warping, which is inconsistent with the earthquake rupture that crosses these terraces. Given these, we argue that the prediction of the northeastern turn and the location of the Chi-Chi earthquake rupture would have been difficult.

The current neotectonic and seismic hazard studies in Taiwan mainly focus on evaluating the activities of mapped faults and identifying active faults based on discrete geomorphic lineaments (e.g., Chang et al. 1998). The way the Chi-Chi earthquake rupture occurs then indicates that these approaches are insufficient. Clearly, great earthquakes can create ruptures that transect, or appear irrelevant to, the mapped fault systems. On the other hand, as shown in this study, geomorphic features that record active tilting/warping and spatial changes in tectonic activity may be helpful to delineate a potential coseismic deformational zone. We maintain that such a regional geomorphic approach is fundamental to understanding an area's neotectonic framework, and can be widely applied to supplement the current neotectonic study. Of course, uncertainties exist as to how we could use such neotectonic data to pre-locate precisely earthquake ruptures.

Acknowledgements We thank Dr. Wen-Shan Chen of National Taiwan University for his helpful discussion. We also greatly appreciate Dr. Ping-Mei Liew of National Taiwan University and Dr. Hui-Cheng Chang of the Central Geological Survey, R.O.C. for their kindly logistics support of this study.

\section{REFERENCES}

Bonilla, M. G., 1977: Summary of Quaternary faulting and elevation changes in Taiwan. Mem. Geol. Soc. China, 2, 43-55.

Bull, W. B., 1991: Geomorphic Responses to Climatic Change. Oxford University Press, New York, 326 pp.

Central Geological Survey, 1999: Report of the Geological Survey of the 1999 Chi-Chi Earthquake. Central Geol. Surv. R.O.C., 315 pp. (in Chinese).

Chang, H. C., C. W. Lin, M. M. Chen, and S. T. Lu, 1998: An Introduction to the Active Faults of Taiwan-Explanatory Text of the Active Fault Map of Taiwan, scale 1:500, 000. Central Geol. Surv. Special Publication 10, 103pp. (in Chinese).

Chang, S. C., 1994: Geological map of Tachia. Central Geol. Surv. R.O.C., scale 1:50,000.

Chang, S. L., 1971: Subsurface geologic study of the Taichung basin. Petrol. Geol. Taiwan, 
8, 21-45.

Chen, W. S., Y. G. Chen, T. K. Liu, N. W. Huang, C.C. Lin, S.H. Sung, and K.J. Lee, 2000: Characteristics of the Chi-Chi earthquake ruptures. Bull. Central Geol. Surv. special publication, 12, 139-154 (in Chinese).

Chen, Y. G., and T. K. Liu, 1991: Radiocarbon dates of river terraces along the lower Tahanchi, northern Taiwan: their tectonic and geomorphic implications. Proc. Geol. Soc. China, 34, 337-346.

Chinese Petroleum Corporation, 1974: Geological map of Miaoli. Chinese Petrol. Corp., scale 1: 100,000 .

Chinese Petroleum Corporation, 1982: Geological map of Taichung. Chinese Petrol. Corp., scale 1: 100,000.

Huang, C. S., H. C. Chang, and H. C. Liu, 1993: Geological exploration of the Chukou fault, Southern Taiwan (II). Report of the Risk Prevention Technique, National Science Council, 82-10, 12pp. (in Chinese).

Huang, C. T., 1982: Fengyuan division. In Report of Engineering Geological Survey on the Hill-slope-situated Community (3-2): Taichuang Region. Central Geol. Surv. R.O.C., 1-72. (in Chinese).

Koons, P. O., 1995: Modeling the topographic evolution of collisional belts. Annu. Rev. Earth Planet. Sci., 23, 375-408.

Ku, C. C., 1963: Photogeologic study of terraces in northwestern Taiwan. Proc. Geol. Soc. China, 6, 51-60.

Lee, C. F., 2000: Geological map of Dungshih. Central Geol. Surv. R.O.C., scale 1: 50,000.

Lee, Y. H., W. Y. Wu, T. S. Shih, S. T. Lu, M. L. Hsieh, C. W. Lin, W. C. Huang, and H. C. Chang, 2000: Deformation characteristics of surface ruptures of the Chi-Chi earthquake, east of the Pifeng bridge. Bull. Central Geol. Surv. special publication, 12, 19-40 (in Chinese).

Leland, J., M. R. Reid, D. W. Burbank, R. Finkel, and M. Caffee, 1998: Incision and differential bedrock uplift along the Indus River near Nanga Parbat, Pakistan Himalaya, from ${ }^{10} \mathrm{Be}$ and ${ }^{26} \mathrm{Al}$ exposure age dating of bedrock straths. Earth Planet. Sci. Letters, 154, 93-107.

Lin, C. C., 1957: Topography of Taiwan. Publication of the Taiwan Provincial Documentary Committee, 424pp. (in Chinese).

Meng, C. Y., 1963: San-I overthrust. Petrol. Geol. Taiwan, 2, 1-20.

Miall, A. D., 1995: Collision-related foreland basins, in C.J. Busby, and R.V. Ingersoll, eds., Tectonics of Sedimentary Basins. Blackwell Science Inc., Cambridge, 393-424.

Pazzaglia, F. J., T. W. Gardner, and D. J. Merritts, 1998: Bedrock fluvial incision and longitudinal profile development over geologic time scales determined by fluvial terraces, in K.J. Tinkler, and E.E. Wohl, eds., Rivers Over Rock: Fluvial Processes in Bedrock Channels. American Geophys. Union, Geophys. Monograph 107, 207-235.

Shih, T. T., K. S. Tseng, K. S. Yang, and M. Y. Hsu, 1986: Active faults and geomorphic surfaces of the Hsinshe terraces. Geomorphic Bull., 5, 29-39. (in Chinese).

Suppe, J., Y. H. Lee, Y. G. Chen, and J. H. Hung, 2000: Coseismic fault-bend folding: Fold 
scarp formation in the 1999 Chi-Chi earthquake (M7.6), Taiwan fold-and-thrust belt: American Geophysical Union 2000 Fall Meeting Abstract, F874-F875.

Torii, K., 1934: Geological map of Dungshih. Taiwan Bureau of Productive Industries Government, scale 1: 50,000. 